\title{
The Mechanism Behind the Oxidation Protection of High Mg Al Alloys with Beryllium
}

\begin{abstract}
NICHOLAS SMITH, ANNE KVITHYLD, and GABRIELLA TRANELL
The addition of beryllium to Al-Mg alloys is known to cause a dramatic decrease in oxidation; however, the mechanism behind this protective effect is not yet fully understood. To aid in finding an alternative to the toxic $\mathrm{Be}$, a fundamental study of Be additions has been carried out. Industrial samples containing $2 \mathrm{ppm}$ Be and a model alloy with $100 \mathrm{ppm}$ Be were oxidized at temperatures between $550^{\circ} \mathrm{C}$ and $750{ }^{\circ} \mathrm{C}$ in a horizontal tube furnace. The oxide layer and oxide-metal interface were investigated using SEM, FIB, and XPS. It was found that Be forms a uniform oxide layer at the oxide-metal interface which slows the diffusion of $\mathrm{Mg}$ and $\mathrm{Al}$ from the metal into the oxide layer resulting in a reduced oxidation rate and an increase in the time for breakaway oxidation to occur.
\end{abstract}

https://doi.org/10.1007/s11663-018-1340-6

(c) The Author(s) 2018

\section{INTRODUCTION}

BERYLLIUM additions in ppm levels have long been used by the aluminum industry as a means of reducing the excessive oxidation that can occur when producing $\mathrm{Al}$ alloys with an elevated $\mathrm{Mg}$ content. Through TGA experiments, the effects of Be were well documented by Balicki already in 1958, Thiele in 1960, and Cochran in 1976. ${ }^{[1-3]}$ The benefits of Be additions come in reducing the total amount of oxidation over short timeframes, as well as increasing the time until the onset of breakaway oxidation. However, owing to the limited ability of many quantification techniques to detect trace amounts of $\mathrm{Be}$, the mechanism by which Be influences the oxidation has not been fully understood. Due to the significant health risks posed by $\mathrm{Be}$ and $\mathrm{BeO}$, especially to the workers in the aluminum casthouses, the use of Be is restricted, and alternative methods are preferred. ${ }^{[4]}$

The addition of $\mathrm{Mg}$ to an $\mathrm{Al}$ alloy causes an $\mathrm{MgO}$ oxide layer to form, which is further transformed to $\mathrm{MgAl}_{2} \mathrm{O}_{4}$; once all the $\mathrm{Mg}$ is oxidized from the melt, these oxides are considered nonprotective in terms of preventing further oxidation. Mg-containing alloys will initially oxidize at a low rate; however, after a period of time ranging from minutes to hours, there will be a sudden and sharp increase in the oxidation rate, known as breakaway oxidation that will continue until all the $\mathrm{Mg}$ in the melt is

NICHOLAS SMITH and GABRIELLA TRANELL are with the NTNU, Alfred Getz Vei 2, 7034 Trondheim, Norway. Contact e-mail: nicholas.smith@ntnu.no ANNE KVITHYLD is with the SINTEF,

Sluppen, P.O. Box 4760, 7465 Trondheim, Norway.

Manuscript submitted February 20, 2018.

Article published online July 20, 2018 oxidized. The oxidation will result in a notable loss of $\mathrm{Mg}$ from the melt. Therefore, extra steps are generally required when producing alloys with a high $\mathrm{Mg}$ content to minimize the oxidation. Ppm level additions of Be have been shown to reduce both the amount of oxidation and delay the onset of breakaway oxidation. This results in a reduction of the amount of $\mathrm{Mg}$ lost to oxidation and a reduction in the number of oxide inclusions that enter the melt during casting. ${ }^{[1-3,5]}$ The focus of this study will be on describing the formation of the oxide layer in the presence of Be during the incubation period of oxide growth, rather than breakaway oxidation, as the former is the most important time period with respect to industrial Al production - as the primary aim of oxidation control in the casthouse is to remain in the incubation stage and avoid catastrophic breakaway oxidation.

To better understand the mechanism behind how trace $\mathrm{Be}$ additions can result in a marked drop in the oxidation of Al-Mg alloys, a series of experiments were undertaken to characterize the oxide layer and the effects of Be on the layer.

\section{EXPERIMENTAL}

The primary experimental study focused on oxidation experiments conducted in a horizontal tube furnace; however, supplementary metal-oxide reaction and oxide-stability experiments were carried out to support the findings.

\section{A. Oxidation Experiments}

Figure 1 shows one of the two horizontal tube furnaces and the sample loading system utilized to carry out the oxidation experiments. Ground $(22 \mu \mathrm{m})$ or polished $(1 \mu \mathrm{m})$ flat samples measuring approximately 
$25 \times 15 \times 1.5 \mathrm{~mm}$ were placed in an alumina boat suspended in the furnace and held for a set time and temperature under an air atmosphere in the furnace as shown in Figure 1. This method gives samples that can be analyzed from various oxidation times, showing how the oxide morphology evolves with time. The samples were removed from the furnace after the required holding time and analyzed by means of a scanning electron microscope (SEM), dual-beam focused ion beam miller (FIB), and X-ray photoelectron spectroscopy (XPS). Table I shows the experimental matrix for the experiments done in the tube furnace.

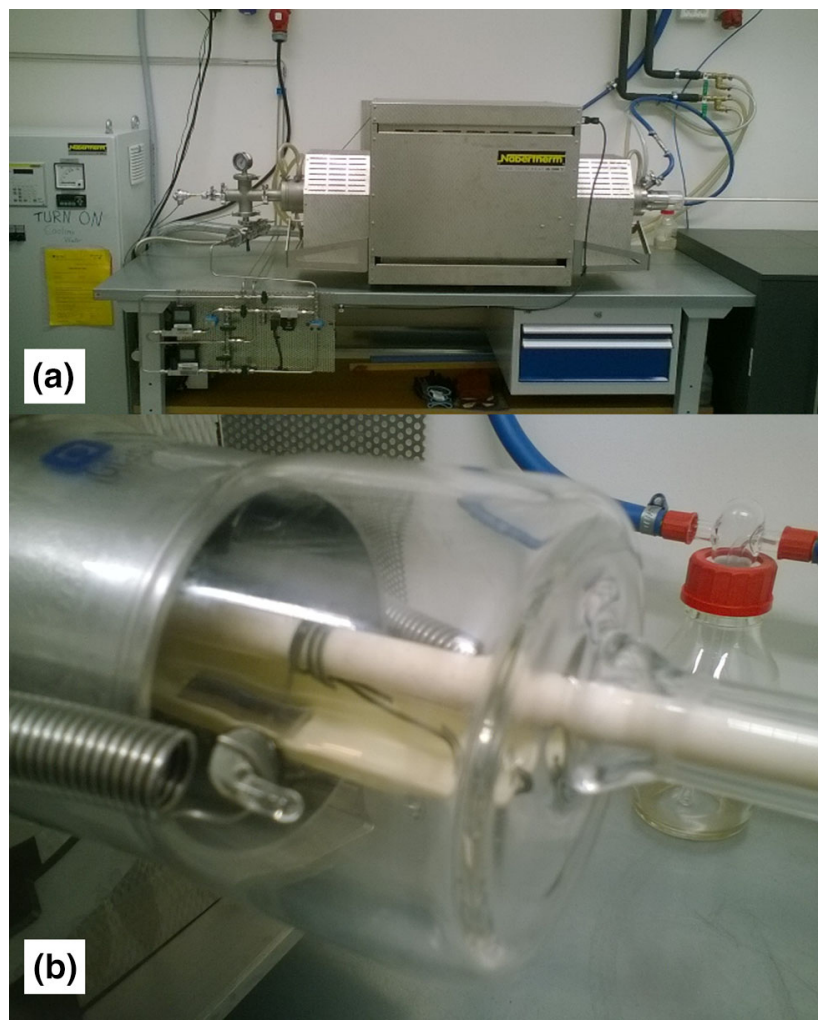

Fig. 1-(a) Horizontal tube furnace used for oxidation tests of 100 ppm Be samples. (b) Sample loading system for the horizontal tube furnace with sample in alumina boat.
The first series of experiments were carried out on industrially produced 5XXX series $\mathrm{Al}$ alloys. Two different alloys were used: one containing $2 \mathrm{ppm}$ of $\mathrm{Be}$ and the other being Be free. Besides the Be content, both alloys were of the same grade and had a similar $\mathrm{Mg}$ content (4.7 pct). Samples were cut with a $\mathrm{SiC}$ abrasive saw and ground to $22 \mu \mathrm{m}$ with $\mathrm{SiC}$ paper on all sides. To minimize oxidation at room temperature, the sample was placed in the furnace within 30 minutes of the final grinding. Samples were held at temperatures between $550{ }^{\circ} \mathrm{C}$ and $750{ }^{\circ} \mathrm{C}$ for 10,30 , or 120 minutes with the mass of each sample measured before and after oxidation to find the percentage mass gain due to oxidation.

To enhance the effects of $\mathrm{Be}$, a second set of experiments was carried out on a model alloy with an elevated Be content over what is typically found in industrial alloys; this alloy consisted of $100 \mathrm{ppm}$ of Be and $4.5 \mathrm{pct} \mathrm{Mg}$ in pure Al. It was assumed that the higher level of Be would only act to enhance the effects and aid in the detection of $\mathrm{Be}$ without changing the overall oxidation protection mechanism. The alloy was made from 99.999 pct pure Al from Puratronic, 99.98 pct pure Mg from Sigma Aldrich, and 99 pet pure Be from Alfa Aesar. First, a 0.5 pct AlBe master alloy was made in an arc melter that passed an electrical current through a tungsten electrode, creating an arc that rapidly melted the metal. The sample was then rapidly cooled on a water-cooled copper plate. This process was repeated several times to ensure a homogeneous alloy. The master alloy plus $\mathrm{Al}$ and $\mathrm{Mg}$ was charged into an alumina crucible and heated in an induction furnace to $850{ }^{\circ} \mathrm{C}$ and held for 15 minutes. It was then sectioned to size, polished to a $1 \mu \mathrm{m}$ finish using a $\mathrm{SiC}$ abrasive saw and standard sample polishing techniques, to allow generation of the best possible chemical composition and depth profile.

\section{B. Sample Analysis}

A FEI Helios NanoLab DualBeam FIB was used to examine the surface of the samples after oxidation. After examination of the surface, the gallium ion beam was used to cut vertically down through the surface of the oxide and into the bulk metal. This allows a cross section of the oxide layer to be examined and the thickness of the layer to be measured.

Table I. Experimental Matrix for Oxidation Experiments of an Al 4.5 Pet Mg Alloy Containing Beryllium

\begin{tabular}{|c|c|c|c|c|c|c|c|}
\hline \multirow[b]{2}{*}{ Temp $\left({ }^{\circ} \mathrm{C}\right)$} & \multicolumn{7}{|c|}{ Time (Min) } \\
\hline & 10 & 30 & 45 & 60 & 90 & 120 & 360 \\
\hline \multicolumn{8}{|l|}{$2 \mathrm{ppm} \mathrm{Be}$} \\
\hline 550 & $\mathrm{X}$ & $\mathrm{X}$ & & & & $\mathrm{X}$ & \\
\hline 700 & $\mathrm{X}$ & $\mathrm{X}$ & & & & $\mathrm{X}$ & \\
\hline 750 & $\mathrm{X}$ & $\mathrm{X}$ & & & & $\mathrm{X}$ & \\
\hline \multicolumn{8}{|l|}{100 ppm Be } \\
\hline 550 & & $\mathrm{X}$ & $\mathrm{X}$ & $\mathrm{X}$ & $X$ & & $\mathrm{X}$ \\
\hline 700 & & & & & & & $\mathrm{X}$ \\
\hline 750 & & $\mathrm{X}$ & & $\mathrm{X}$ & & $\mathrm{X}$ & \\
\hline
\end{tabular}




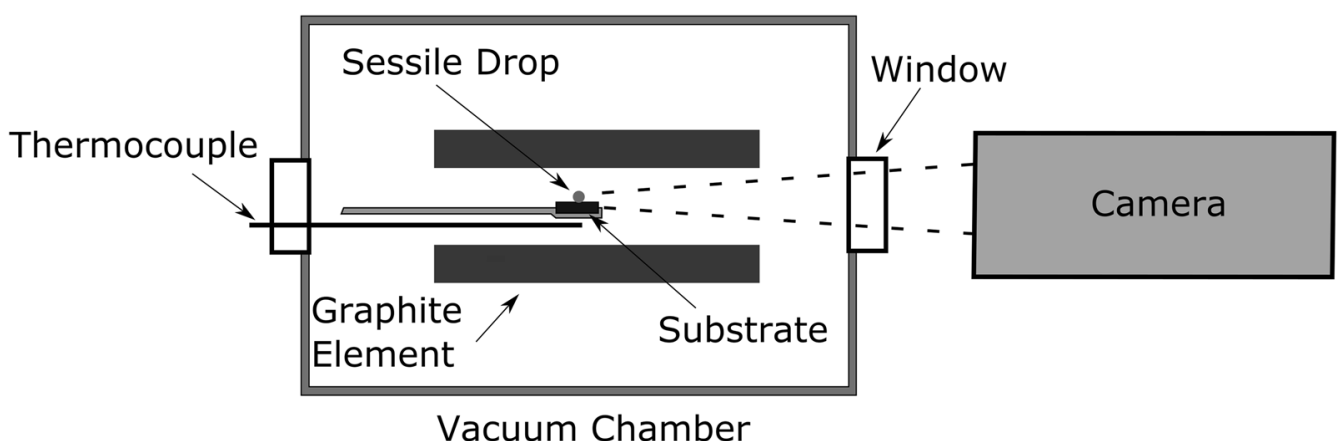

Fig. 2-Sessile drop furnace setup used to study the reaction and contact angle between oxide substrates and AlBe alloys under a high vacuum at $1100{ }^{\circ} \mathrm{C}$.

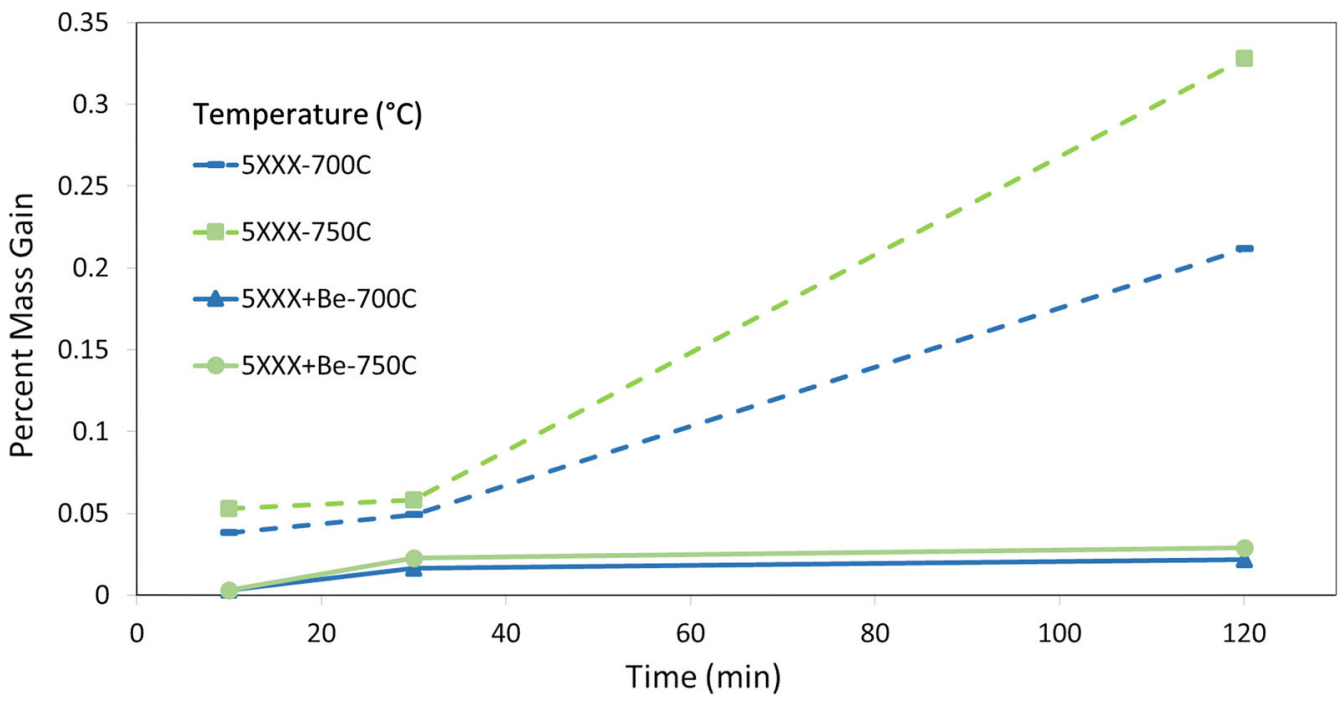

Fig. 3-Percentage mass gains in samples with and without $2 \mathrm{ppm}$ Be oxidized in synthetic air for 10,30 , or 120 min at $700{ }^{\circ} \mathrm{C}$ and $750{ }^{\circ} \mathrm{C}$ showing a significant decrease in the total amount of oxidation with the addition of $2 \mathrm{ppm}$ Be.

A Thermofisher Thetaprobe XP Spectrometer was used to create a XPS composition depth profile from the top surface through the oxide layer into the base metal. To create the depth profile, argon sputtering was used with an estimated sputtering rate of $8 \mathrm{~nm}$ per analysis cycle (120 seconds of sputtering time).

\section{Metal-Oxide Reaction}

The effects of $\mathrm{Be}$ on an $\mathrm{Al}$ drop in contact with $\mathrm{Al}_{2} \mathrm{O}_{3}$ and $\mathrm{MgO}$ substrates was measured using a sessile drop furnace as seen in Figure 2. This setup allowed observation of any reactions between the metal and substrate, as well as measuring the metal-substrate contact angle.

Pure $\mathrm{Al}$ with 0,30 , or $60 \mathrm{ppm}$ of $\mathrm{Be}$ was tested on both $\mathrm{Al}_{2} \mathrm{O}_{3}$ and $\mathrm{MgO}$ substrates. In order to test the contact angle between the metal droplet and the substrate without interference of the oxide skin on the Al drop, the oxide skin was removed under a high vacuum/low oxygen partial pressure. Under a high vacuum, the $\mathrm{Al}_{2} \mathrm{O}_{3}$ skin will become less stable, and there is a decrease in thickness of the skin as the flux of oxygen away as $\mathrm{AlO}$ gas will exceed the flux of oxygen into the skin. The rate of this evaporation is temperature dependent, and, at temperatures over $1100{ }^{\circ} \mathrm{C}$, the oxide skin can be completely removed in a short time. ${ }^{[6]}$ Once the skin has been removed, a stable contact angle can be measured. In the experiments, the samples were held for two hours under a $1.5 \times 10^{-5}$ mbar vacuum at $1100^{\circ} \mathrm{C}$.

\section{Oxide Stability}

Experiments to better understand the stabilities of $\mathrm{BeO}, \mathrm{MgO}$, and $\mathrm{Al}_{2} \mathrm{O}_{3}$ when mixed were carried out by mixing these three oxides in powder form in a 1:1:1 and a 1:1:2 ratio (BeO:MgO: $\mathrm{Al}_{2} \mathrm{O}_{3}$ ) and placed in $\mathrm{Mo}$ crucible and held at $1100{ }^{\circ} \mathrm{C}$ for 7 hours. The samples were subsequently analyzed using a D8 Focus powder $\mathrm{X}$-ray Diffractometer (XRD) to see which phases had formed. The XRD scan was completed with a two theta angle ranging from 15 to $105 \mathrm{deg}$. This range captured all the major known peaks associated with the ternary $\mathrm{BeO}-\mathrm{MgO}-\mathrm{Al}_{2} \mathrm{O}_{3}$ system. 

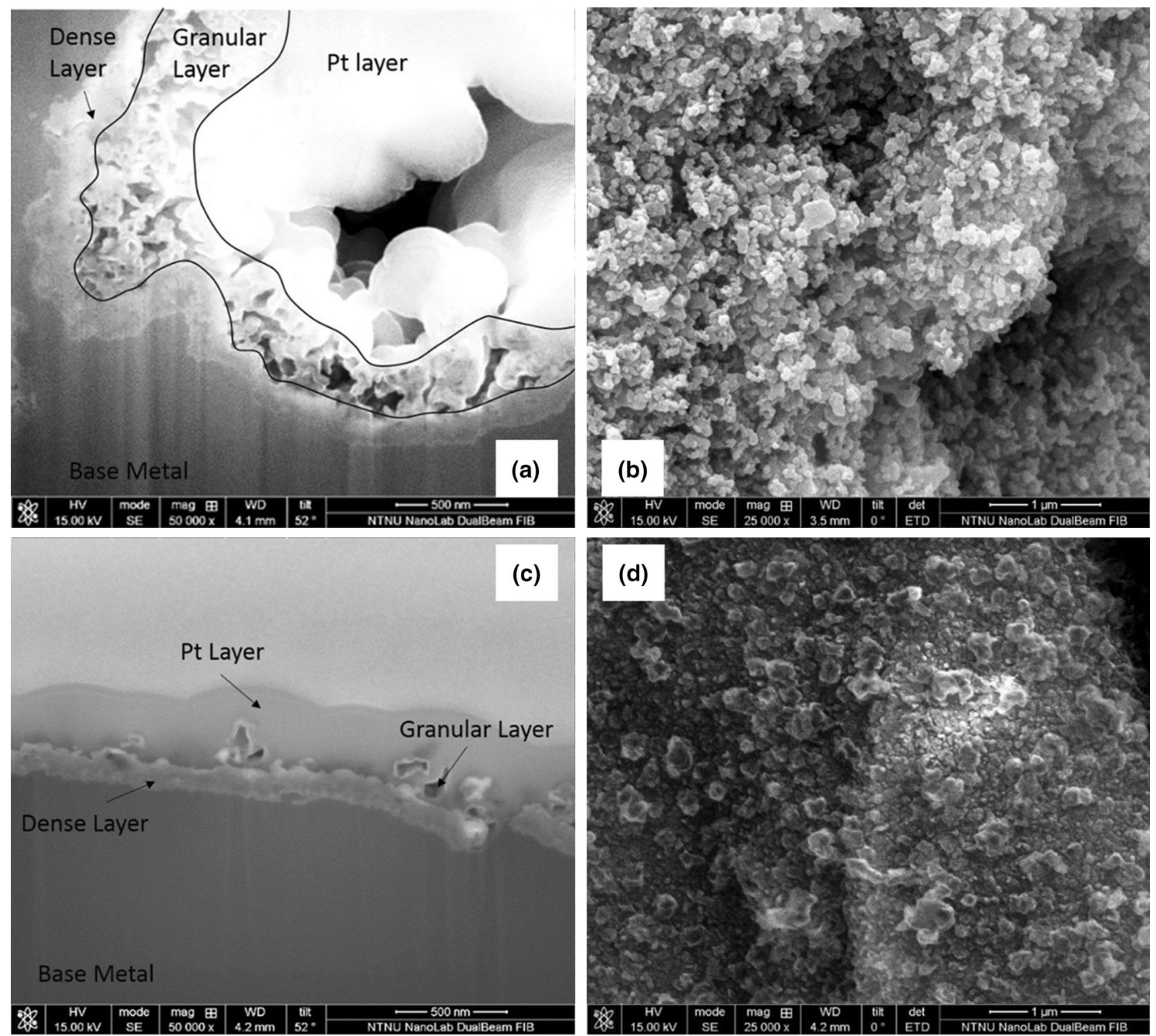

Fig. 4-Samples from oxidation experiments in synthetic air in the horizontal tube furnace shown in $(a)$. Cross section of sample without Be from $120 \mathrm{~min}$ at $700{ }^{\circ} \mathrm{C}$ showing large amounts of granular growth on the top of the oxide layer. $(b)$ Top surface of sample without Be from 120 min at $700{ }^{\circ} \mathrm{C}$ with granular growth covering the entire sample surface. $(c)$ Cross section of sample with 2 ppm Be from 120 min at $700{ }^{\circ} \mathrm{C}$ with only minor granular growth being visible. $(d)$ Surface of sample with 2 ppm Be from 120 min at $700{ }^{\circ} \mathrm{C}$ showing only minimal coverage of the granular layer.

\section{RESULTS}

\section{A. Beryllium in Industrial Al-Mg-Be Samples}

\section{Mass gain}

The addition of $2 \mathrm{ppm}$ of $\mathrm{Be}$ was found to have a significant impact on the total amount of oxidation/ sample mass gain. Figure 3 shows the percentage mass gain of the samples with and without $2 \mathrm{ppm} \mathrm{Be}$. The addition of Be resulted in up to a tenfold decrease in the mass gain. ${ }^{[7]}$ These results are in agreement with previous mass gain and TGA analysis conducted on $\mathrm{Be}$ in $\mathrm{Mg}-\mathrm{Al}$ alloys. ${ }^{[1-3]}$

\section{Surface and cross-sectional morphology}

The addition of Be had a clear impact on the morphology of the oxide layer. Figures 4(a) through (d) shows the top surface and cross section of samples oxidized at $700{ }^{\circ} \mathrm{C}$. In Figures 4(a) and (b), two distinct oxide layers can be seen on the sample without Be: a dense layer adjacent to the metal, and a granular layer on top of the dense layer. The platinum layer above the granular layer in the cross-section figures was deposited by the FIB during the process of making the cross section to protect the integrity of the granular layer from the ion beam. With the addition of Be, the thickness of 


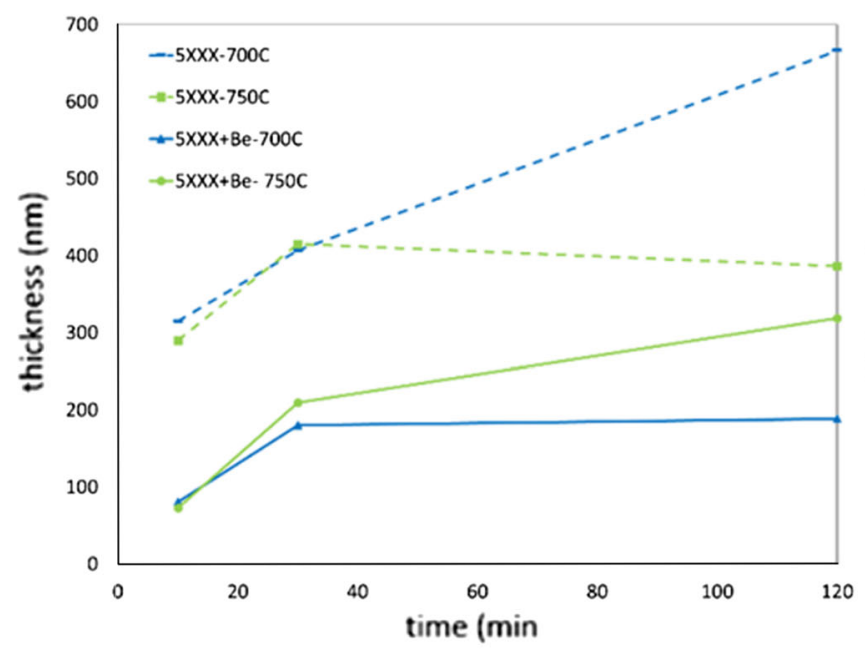

(a)

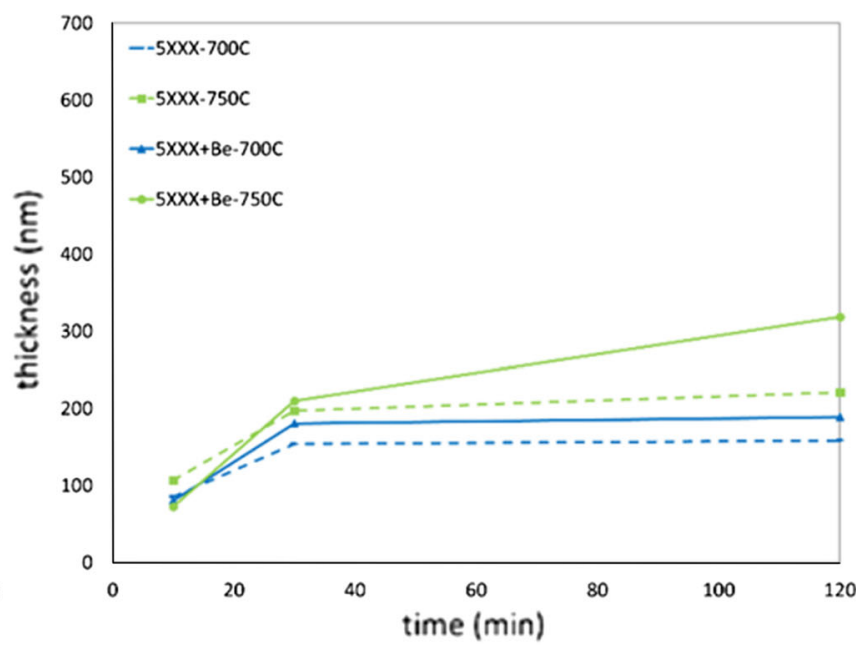

(b)

Fig. 5-Measured oxide layer thicknesses of samples oxidized in air at $700{ }^{\circ} \mathrm{C}$ and $750{ }^{\circ} \mathrm{C}$. $(a)$ The thickness of the entire oxide layer. $(b)$ The thickness of only the dense oxide layer.
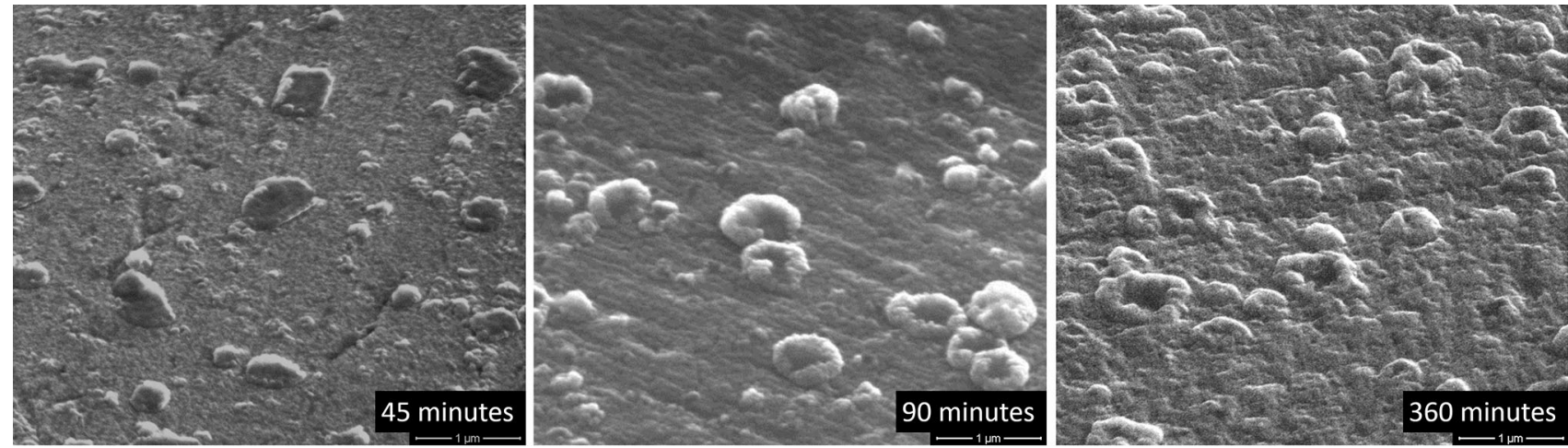

Fig. 6 - FIB images from 45, 90, and 360 min of oxidation in air at $550{ }^{\circ} \mathrm{C}$ on sample with $100 \mathrm{ppm}$ Be, showing the rapid formation of growths on the surface and envelopment of the growths by the surrounding oxide layer with time.

the granular layer is significantly reduced as can be seen in Figures 4(c) and (d) where the amount of granular layer can be seen to be reduced to near zero, whereas the dense layer has a nearly consistent thickness between the two alloys. The granular layer is made up of many small, often faceted granules that grow out of the dense oxide layer creating an open network of oxide. ${ }^{[7]}$ This layer is similar in appearance to $\mathrm{MgO}$ oxide layer found by other researchers on Al-Mg alloys. ${ }^{[3,8,9]}$

Figure 5(a) shows the thickness of the entire oxide layer measured from the FIB cross sections. Exact measurement of the granular layer thickness was not possible due to the uneven nature of the layer, and therefore, the thickness of this layer should be taken as an indication of the approximate thickness, not the exact thickness. Figure 5(b) shows the thickness of just the dense layer. A comparison of the thickness of the oxide layers shows that the thickness of the dense layer is similar between the samples with and without $\mathrm{Be}^{[7]}$ The significant difference between the Be-containing and Be-free alloys is the granular layer thickness.

\section{B. Model 100 ppm Al-Mg-Be Samples}

1. Surface and cross-sectional morphology

Examination in the FIB of samples with $100 \mathrm{ppm}$ Be oxidized at $550{ }^{\circ} \mathrm{C}$ for 45,90 , and 360 minutes showed that within the first 45 minutes, the surface of the sample was covered in growths measuring up to $0.5 \mu \mathrm{m}$ across. These growths appeared to remain nearly constant in size for longer oxidation times, as illustrated by Figure 6. The oxide surrounding these growths was seen to grow and began to envelop the growths after 360 minutes of oxidation time. These growths are not present on a reference sample that was oxidized under the same conditions, but contained no Be as shown in Figure 7; rather the surface was covered in large granular $\mathrm{MgO}$ growths. ${ }^{[10]}$

The formation of the growths was not uniform across the entire sample surface with the number of growths varying from region to region. Grain boundaries particularly appeared to be nucleation sites for the growths as seen in Figure $8 .{ }^{[10]}$ 


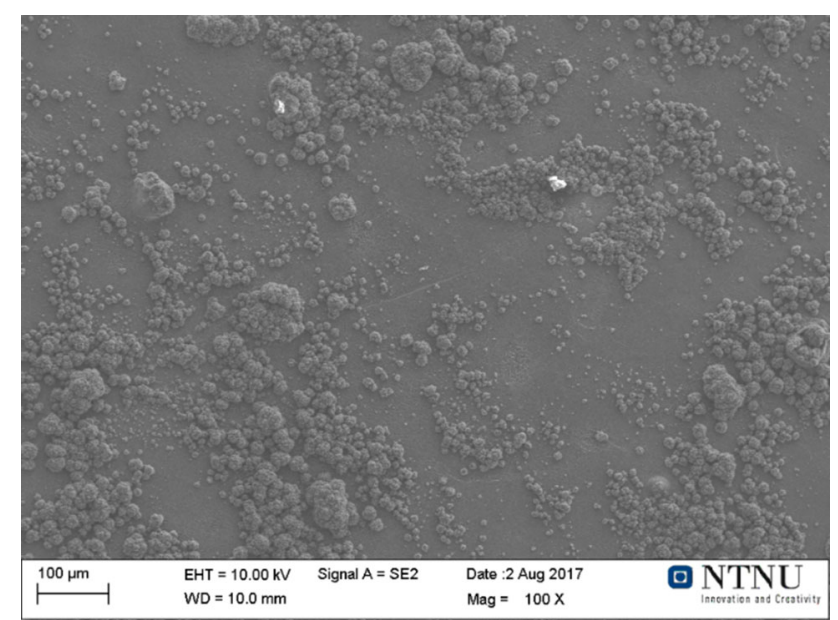

Fig. 7-Surface of reference sample without Be oxidized for $240 \mathrm{~min}$ at $550{ }^{\circ} \mathrm{C}$ in air showing the large granular $\mathrm{MgO}$ growths on the surface, but no smaller, dense growths, as seen on the Be-containing sample (Fig. 6).

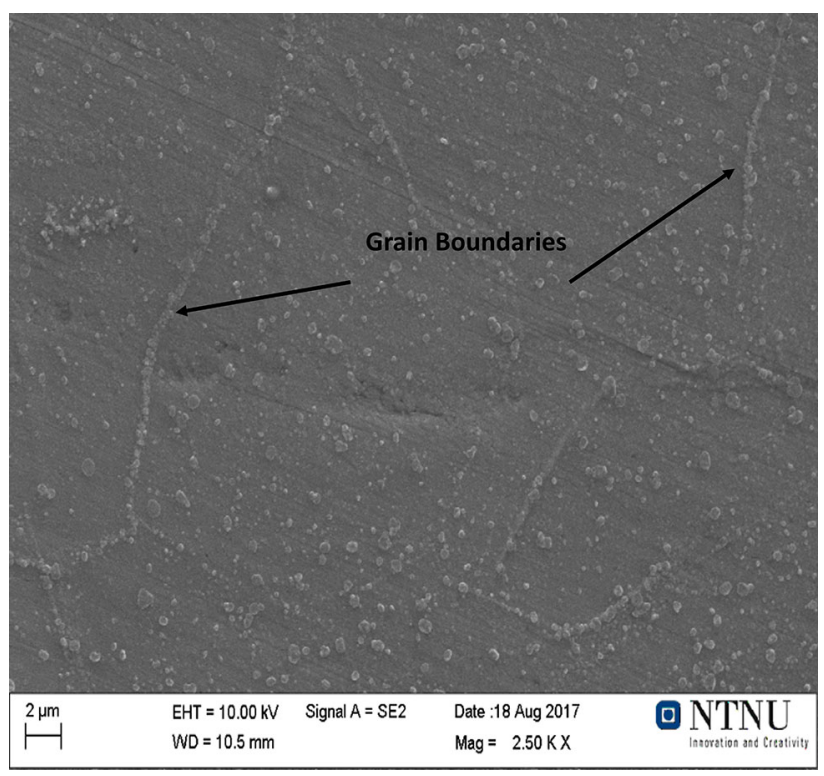

Fig. 8-100 ppm Be sample oxidized for $360 \mathrm{~min}$ at $550{ }^{\circ} \mathrm{C}$ in air showing preferential growth along the grain boundaries.

\section{Composition}

Samples for the XPS were sectioned from the $100 \mathrm{ppm}$ sample oxidized at $550{ }^{\circ} \mathrm{C}$ for 60 and 360 minutes. The results of the XPS are given in Figures 9 and $10 .^{[10]} \mathrm{In}$ these figures, an increase in sputtering time indicates an increase in depth taking the top surface of the oxide to be the top and moving downward towards the bulk aluminum metal. Due to the growths that formed on the surface and the uneven sputtering rate that resulted from these growths, it was not possible to accurately calculate depth from sputtering time. A corresponding oxygen ion curve exists for each of the metal oxide curves given in Figures 9 and 10, however, these have been omitted from the figures for simplicity. It can be seen that for both oxidation times the top surface of the oxide layer is $\mathrm{MgO}$ (far left in Figures 9 and 10). Downwards towards the metal the amount of $\mathrm{Al}$ oxide increases followed by an increase in the metallic Al concentration. Further downward, a clear $\mathrm{BeO}$ signal forms, and the $\mathrm{MgO}$ signal decreases to zero. There is little difference between the 60 and 360 minute samples with exception of the thickness of each layer and the ratio of the $\mathrm{Be}$ oxide to $\mathrm{Al}$ oxide signals. Both XPS curves show that the $\mathrm{Mg}$ metal content in the top part of the metal phase is well below the nominal 4.5 pct, indicating a large loss due to oxidation and evaporation.

Figures 11(a) and (b) shows SEM images of the surface of the 360 minute sample before and after sputtering. Before sputtering, the surface can be seen to have the rough granular appearance typical of $\mathrm{MgO}$, but additionally growths on the top surface that are confirmed to be $\mathrm{MgO}$ by the XPS, are found. After sputtering for 3000 seconds, two distinct phases appear as seen in Figure 11(b). A bright phase on the surface that corresponds with the location of growths on the surface seen in Figure 11(a) and a darker background phase. An Energy Dispersive X-ray Spectroscopy (EDS) scan showed the bright phase is the only oxygen-containing phase present after sputtering. As the XPS shows the $\mathrm{BeO}-\mathrm{Al}_{2} \mathrm{O}_{3}$ phase is the only oxygen-containing phase remaining after sputtering, it should correspond with this bright phase, while the dark phase is the Al metal. This is shown schematically in Figure 12 for both the 60 and 360 minute samples. ${ }^{[10]}$

For the samples oxidized at $700{ }^{\circ} \mathrm{C}$, no large growths were visible on the surface. Rather an uneven surface with a number of small cracks as seen in Figure 13(a). This sample had too much surface topography to allow an XPS analysis. The sample was characterized in the FIB and compared to the $550{ }^{\circ} \mathrm{C}$ sample to help understand the means of oxidation protection on molten samples. Figure 13(b) shows a cross section of the $700{ }^{\circ} \mathrm{C}$ sample where a thin layer ranging from 15 to $50 \mathrm{~nm}$ in thickness exists between $\mathrm{MgO}$ oxide layer and bulk metal. Given the location of this layer in comparison with the samples from $550{ }^{\circ} \mathrm{C}$ it can logically be assumed that this is a $\mathrm{BeO}-\mathrm{Al}_{2} \mathrm{O}_{3}$ layer that formed as a uniform layer across the entire oxide metal interface rather than as the clusters seen with oxidation below the melting point. ${ }^{[10]}$

It is difficult to directly measure the amount of $\mathrm{MgAl}_{2} \mathrm{O}_{4}$ and $\mathrm{BeAl}_{2} \mathrm{O}_{4}$ phase present from the XPS. It is known that for the $\mathrm{MgAl}_{2} \mathrm{O}_{4}$ phase to form the activity of $\mathrm{Mg}$ must be below 0.023 which corresponds to 2.7 at. pct and that $\mathrm{Al}_{2} \mathrm{O}_{3}$ cannot form until after all $\mathrm{MgO}$ has been transformed to $\mathrm{MgAl}_{2} \mathrm{O}_{4} \cdot{ }^{[5]}$ Therefore, any $\mathrm{Al}$ oxide ions found would predominately be associated with the $\mathrm{MgAl}_{2} \mathrm{O}_{4}$ or $\mathrm{BeAl}_{2} \mathrm{O}_{4}$ spinel phases. The XPS scans clearly show the presence of $\mathrm{Al}$ oxide ions indicating that the spinel phase is present. As the $\mathrm{Al}$ oxide signal increases before the $\mathrm{Be}$ signal, the $\mathrm{MgAl}_{2} \mathrm{O}_{4}$ phase is implied. However, at sputtering times over 1600 seconds the $\mathrm{Mg}$ oxide ion signal has decreased to zero, but a strong $\mathrm{Al}$ oxide signal remains indicating the presence of $\mathrm{BeAl}_{2} \mathrm{O}_{4}$. The $\mathrm{Al}$ oxide: $\mathrm{Be}$ oxide ratio shows 


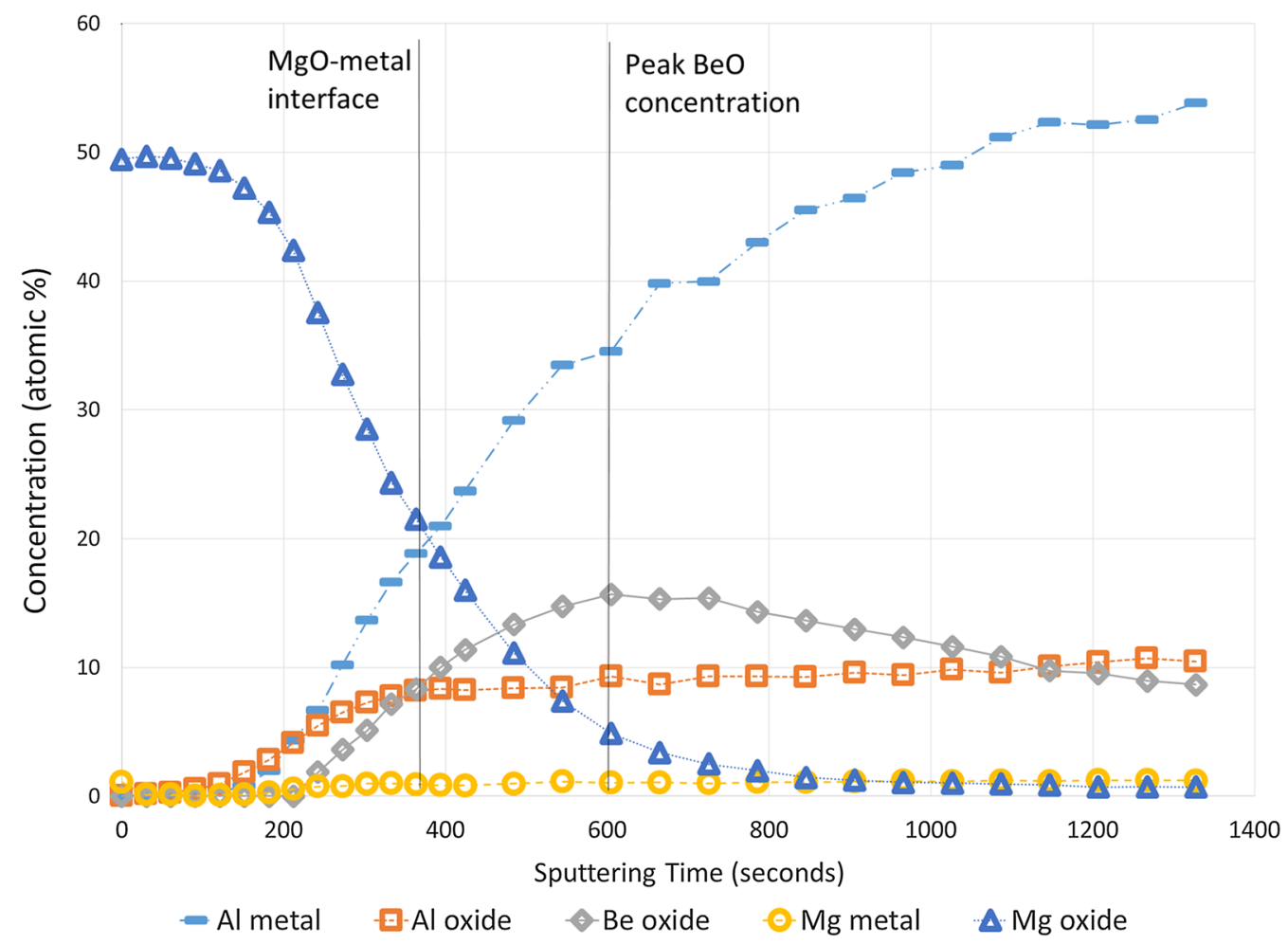

Fig. 9-XPS depth profile of the oxide layer for the sample after $60 \mathrm{~min}$ of oxidation time in air at $550{ }^{\circ} \mathrm{C}$.

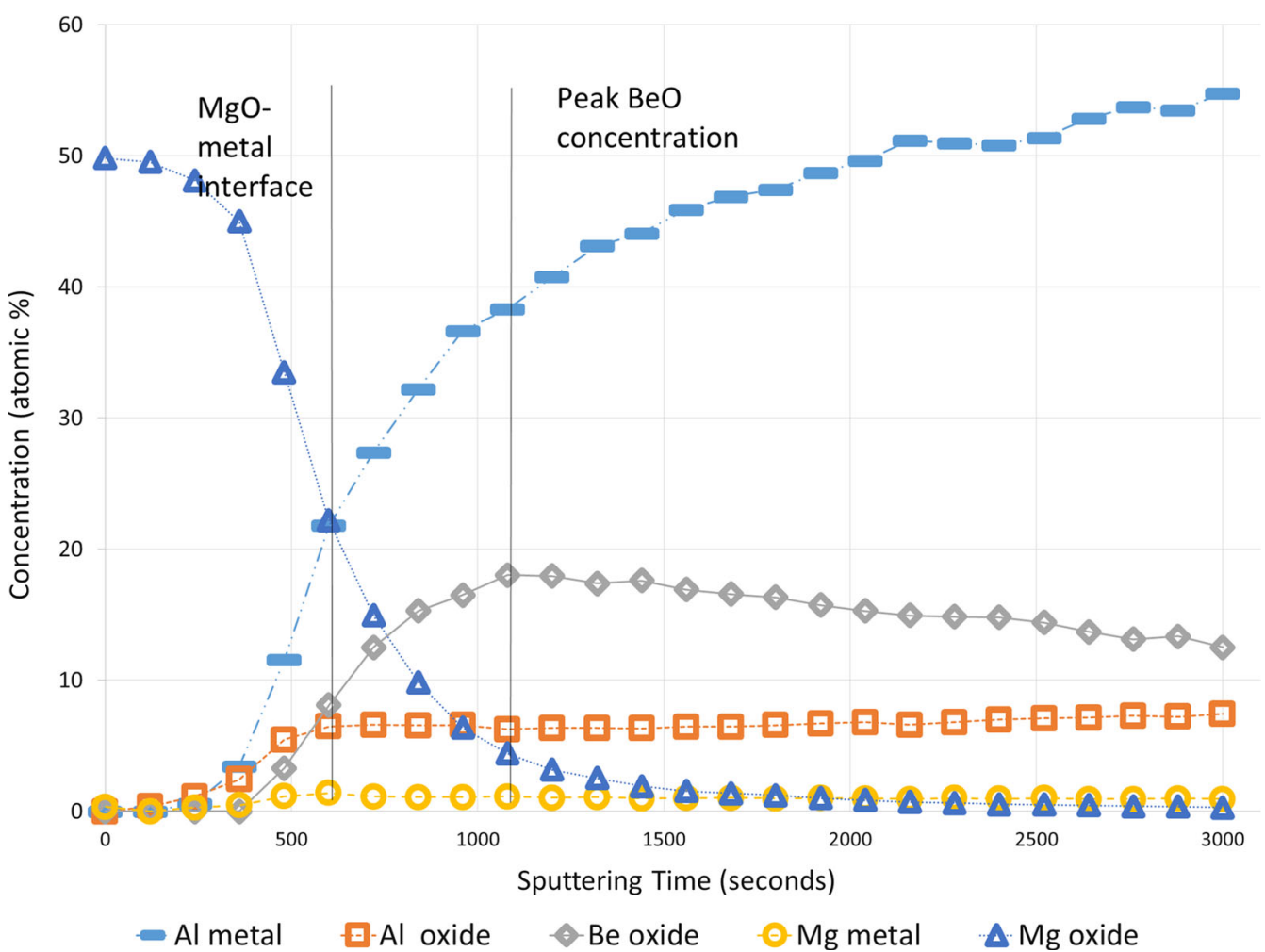

Fig. 10 - XPS depth profile of the oxide layer for the sample after $360 \mathrm{~min}$ of oxidation time in air at $550{ }^{\circ} \mathrm{C}$. 


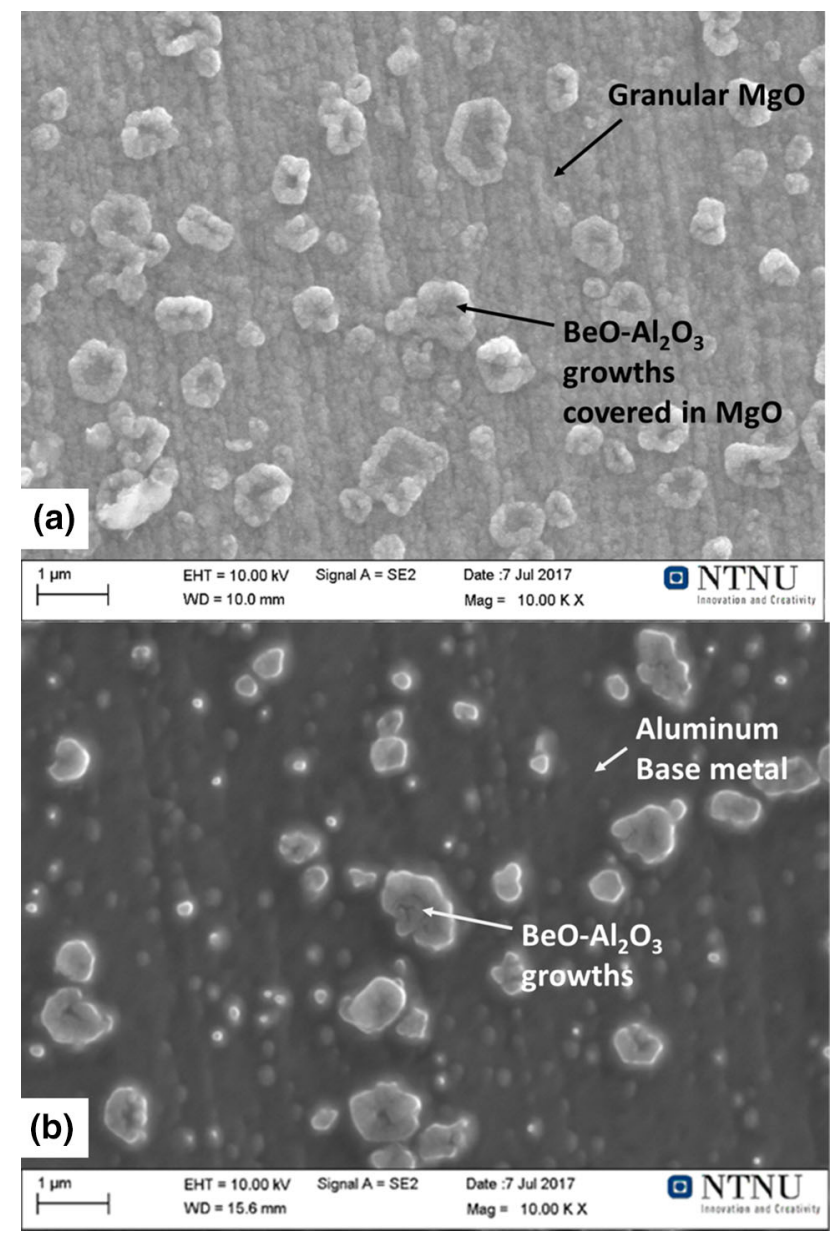

Fig. 11-(a) $100 \mathrm{ppm} \mathrm{Be} \mathrm{sample} \mathrm{oxidized} \mathrm{for} 360 \mathrm{~min}$ at $550{ }^{\circ} \mathrm{C}$ before sputtering, showing surface covered by $\mathrm{MgO}$. (b) Same sample only after sputtering/XPS analysis showing 2 distinct phases: a bright oxide phase and a dark metal phase.

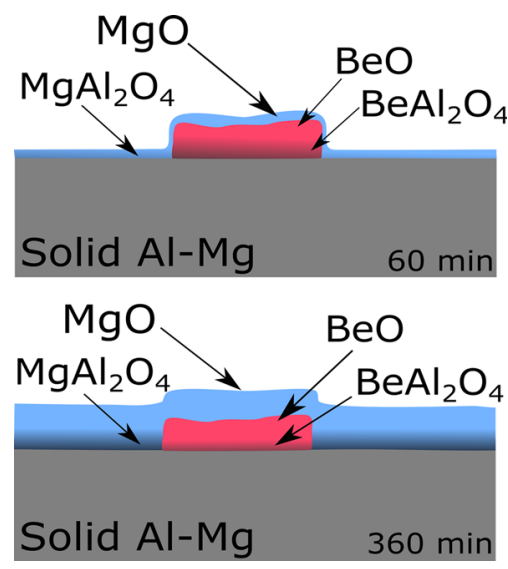

Fig. 12-Schematic showing a cross section of the oxide layer formed on the solid sample after 60 or 360 min of oxidation based on the results of the XPS depth profile and the morphological analysis in the FIB.

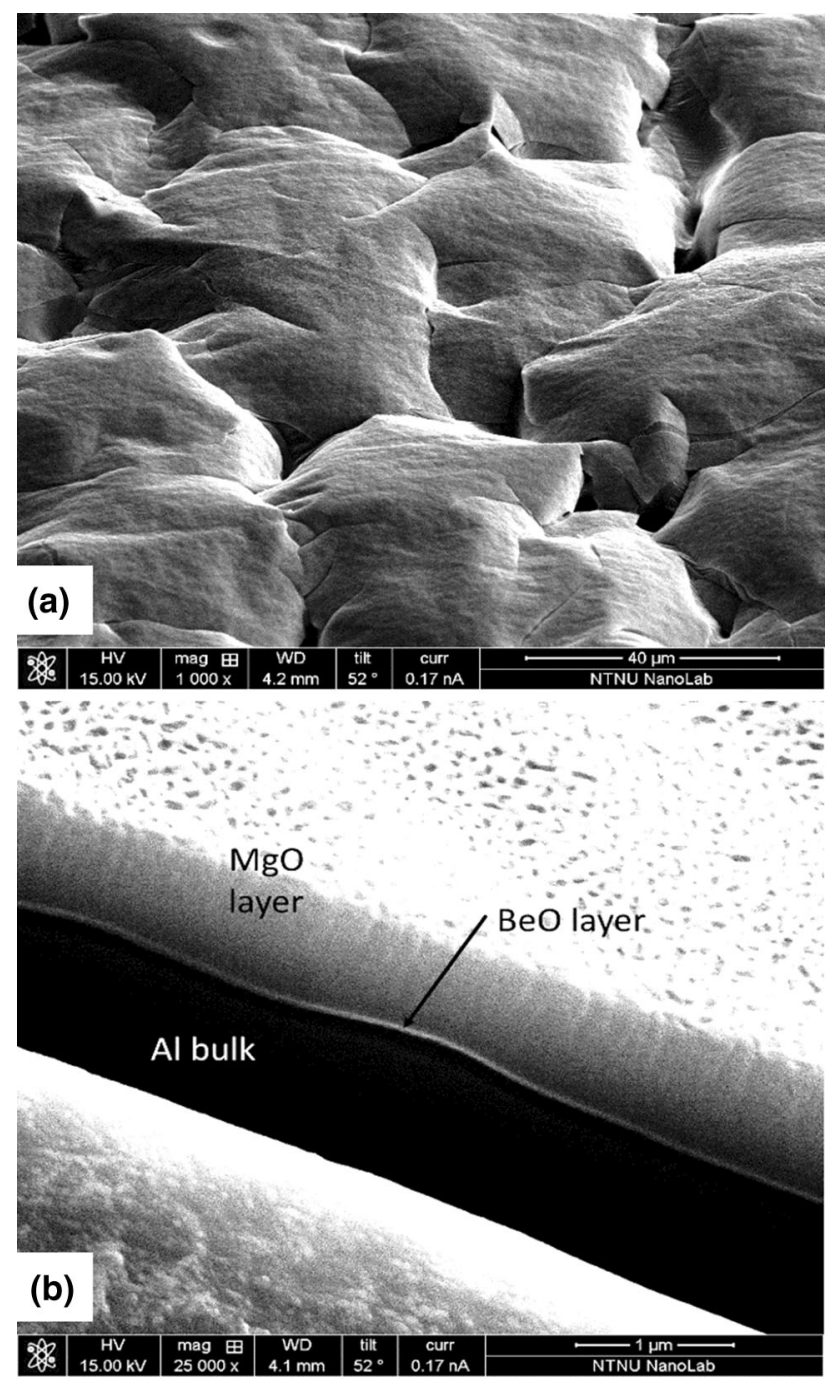

Fig. 13-Sample with $100 \mathrm{ppm}$ Be from 360 min of oxidation at 700 ${ }^{\circ} \mathrm{C}$ in air. (a) Surface showing uneven surface with small cracks. (b) Cross section through oxide layer showing a thin $\mathrm{BeO}$ layer that was found between the $\mathrm{MgO}$ layer and $\mathrm{Al}$ base metal.

that both $\mathrm{BeO}$ and $\mathrm{BeAl}_{2} \mathrm{O}_{4}$ must be present after the entire $\mathrm{Mg}$ oxide layer has been removed by sputtering as both a $\mathrm{Be}$ oxide and an $\mathrm{Al}$ oxide signal remain. For the entire layer to be made up of $\mathrm{BeAl}_{2} \mathrm{O}_{4}$, the $\mathrm{Al}$ oxide: $\mathrm{Be}$ oxide ratio must be $2: 1$. If the ratio is higher than this, then a $\mathrm{BeAl}_{2} \mathrm{O}_{4}-\mathrm{Al}_{2} \mathrm{O}_{3}$ layer would exist. If the ratio is below 2:1 the layer must be $\mathrm{BeAl}_{2} \mathrm{O}_{4}-\mathrm{BeO}$. As the ratio does not reach 2:1 at any point in the depth profile, both $\mathrm{BeO}$ and $\mathrm{BeAl}_{2} \mathrm{O}_{4}$ must be present in the oxide layer.

The $\mathrm{Al}$ oxide:Be oxide ratio increases as the depth increases for both the 60 and 360 minute oxidation samples with a higher ratio seen for the 60 minute sample which exceeds unity for the last 200 seconds. The higher $\mathrm{Al}$ oxide:Be oxide ratio for the shorter oxidation time indicates that the formation of the $\mathrm{BeO}$ layer is 


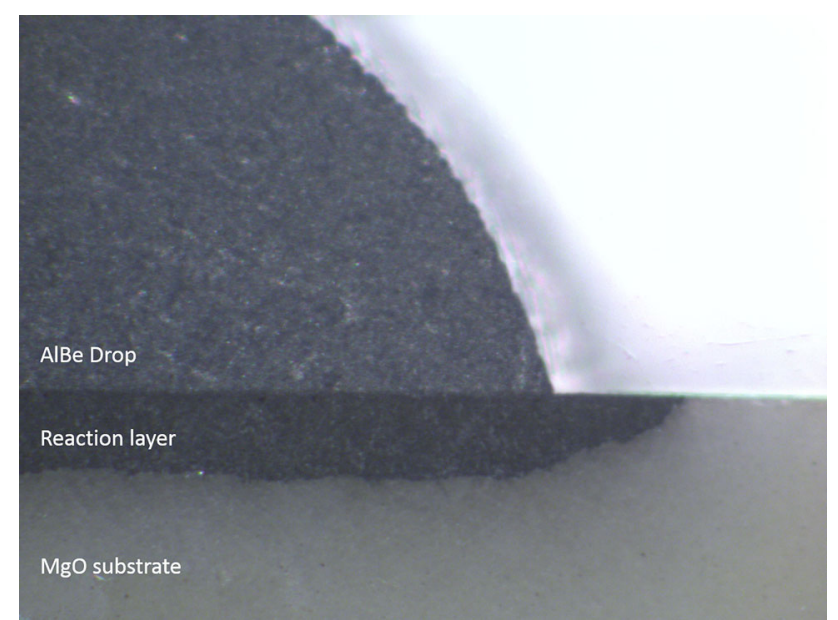

Fig. 14 Sample from Sessile drop furnace showing an Al drop with $60 \mathrm{ppm} \mathrm{Be}$ on $\mathrm{MgO}$ substrate after holding for $15 \mathrm{~min}$ in vacuum at $1100{ }^{\circ} \mathrm{C} . \mathrm{MgAl}_{2} \mathrm{O}_{4}$ reaction layer between the substrate and drop can be seen.

Table II. Contact Angles Measured on $\mathrm{MgO}$ and $\mathrm{Al}_{2} \mathrm{O}_{3}$ with 0,30 , or $60 \mathrm{ppm} B \mathrm{Be}$ in $\mathrm{Al}$

\begin{tabular}{lccc}
\hline & \multicolumn{2}{c}{$\mathrm{Al}_{2} \mathrm{O}_{3}$} & \\
\cline { 2 - 3 } & $15 \mathrm{Min}$ & $60 \mathrm{Min}$ & $\begin{array}{c}\mathrm{MgO} \\
15 \mathrm{Min}\end{array}$ \\
\hline $0 \mathrm{ppm} \mathrm{Be}$ & 85 & 54 & \\
$30 \mathrm{ppm} \mathrm{Be}$ & 88 & 56 & 77 \\
$60 \mathrm{ppm} \mathrm{Be}$ & 90 & 62 & 97 \\
\hline
\end{tabular}

time dependent on the transport of Be from the metal to the oxide layer, with longer times allowing for more concentration and oxidation of $\mathrm{Be}$ in the oxide layer. The $\mathrm{Al}$ oxide:Be oxide ratio would be further reduced if the oxidation occurs above the melting point as the transport of Be to the oxide-metal interface is faster in the liquid phase.

\section{Metal-Oxide Reaction}

Table II shows the contact angles measured for pure Al with 0,30 or $60 \mathrm{ppm} \mathrm{Be}$ on $\mathrm{Al}_{2} \mathrm{O}_{3}$ and $\mathrm{MgO}$ substrates for a temperature of $1140{ }^{\circ} \mathrm{C}$. It was not possible to measure the contact angle at times longer than 15 minutes for the samples on the $\mathrm{MgO}$ substrate. This is due to the strong reaction of the $\mathrm{Al}$ with the substrate. At low pressures, the $\mathrm{MgAl}_{2} \mathrm{O}_{4}$ spinel phase is the stable oxide phase. This reaction occurs rapidly resulting in a reaction layer in the substrate and gassing of $\mathrm{Mg}$ vapor that is deposited on the furnace walls and windows: this reaction can be written as shown in Eq. [1]. The sessile drop sample with the reaction layer is shown in Figure 14. Due to this reaction the angle measured on the $\mathrm{MgO}$ is not stable and is not reliable, but is presented here for thoroughness.

$$
4 \mathrm{MgO}+2 \mathrm{Al}=\mathrm{MgAl}_{2} \mathrm{O}_{4}+3 \mathrm{Mg}
$$

\section{Oxide Stability}

An excerpt of the XRD scans for both the 1:1:1 and 1:1:2 mixing ratios are shown together in Figure 15, and were obtained after analysis of the two different oxide powder mixing ratios. The same peaks were seen in both of the scans. The most significant peaks are the oxides $\mathrm{BeO}, \mathrm{MgO}$ and $\mathrm{Al}_{2} \mathrm{O}_{3}$. The major peaks all vary significantly due to the higher $\mathrm{Al}_{2} \mathrm{O}_{3}$ content in the 1:1:2 sample. Both $\mathrm{BeAl}_{2} \mathrm{O}_{4}$ and $\mathrm{MgAl}_{2} \mathrm{O}_{4}$ were found in the samples. A number of overlapping peaks exist for this system, but at least 3 distinct peaks existed for each $\mathrm{BeAl}_{2} \mathrm{O}_{4}$ and $\mathrm{MgAl}_{2} \mathrm{O}_{4}$. The peaks at 22.15, 27.54 and $56.88 \mathrm{deg}$ are unique to $\mathrm{BeAl}_{2} \mathrm{O}_{4}$ and 31.26, 44.79 and 65.78 deg are unique to $\mathrm{MgAl}_{2} \mathrm{O}_{4}$.

\section{DISCUSSION}

From the morphology studies of the 2 and $100 \mathrm{ppm}$ Be alloys, it can clearly be seen that the growth of the granular layer with time accounts for the bulk of the oxidation occurring on Be-free samples. This oxide growth is rate controlled by the transport of $\mathrm{Mg}$ through the dense oxide layer. The effect of Be reducing the granular $\mathrm{MgO}$ layer formation is clearly visible on the industrial samples where the thickness of granular layer was reduced to near zero with the addition of $2 \mathrm{ppm}$ of Be. This means the addition of Be must slow the transport of $\mathrm{Mg}$ through the oxide layer. This can also be shown by looking at the samples from oxidation at $550{ }^{\circ} \mathrm{C}$ (Figure 6) where the oxide layer surrounding the growths increases in thickness faster than the growths - resulting in the growths being enveloped in the $\mathrm{MgO}$. This indicates that the growths inhibit the oxidation. Further, as seen in Figure 7, the oxidation on a Be-free sample at $550{ }^{\circ} \mathrm{C}$ occurs at preferential sites resulting in large clusters of $\mathrm{MgO}$. The $\mathrm{BeO}$ growths found on the samples containing Be were found at preferential sites such as grain boundaries; it is believed that the $\mathrm{BeO}$ growths form at the preferential sites for $\mathrm{Mg}$ oxidation resulting in a reduction of the large oxide clusters seen on Be-free samples.

The minor increase in the contact angle seen with increasing amounts of $\mathrm{Be}$, i.e. increased wetting is negligible when compared to the error seen with this setup $\pm 5 \mathrm{deg}$. The contact angle results for pure aluminum are in good agreement with those found by Bao. ${ }^{[6]}$ Syvertsen carried out measurements of the oxide skin strength on a liquid $\mathrm{Al}-\mathrm{Mg}$ melt and found that additions of $2 \mathrm{ppm}$ Be had no impact on the skin strength. This offers a confirmation of the wetting results obtained here as the skin strength is partially a measure of the surface tension between the oxide and metal. $^{[11]}$

The rapid reaction of the $\mathrm{Al}$ drop with the $\mathrm{MgO}$ substrate shows that even with $\mathrm{Be}$ additions $\mathrm{MgO}$ will react strongly with liquid aluminum forming the $\mathrm{MgAl}_{2} \mathrm{O}_{4}$ spinel unless the $\mathrm{MgO}$ layer and $\mathrm{Al}$ metal are separated by a protective layer. 


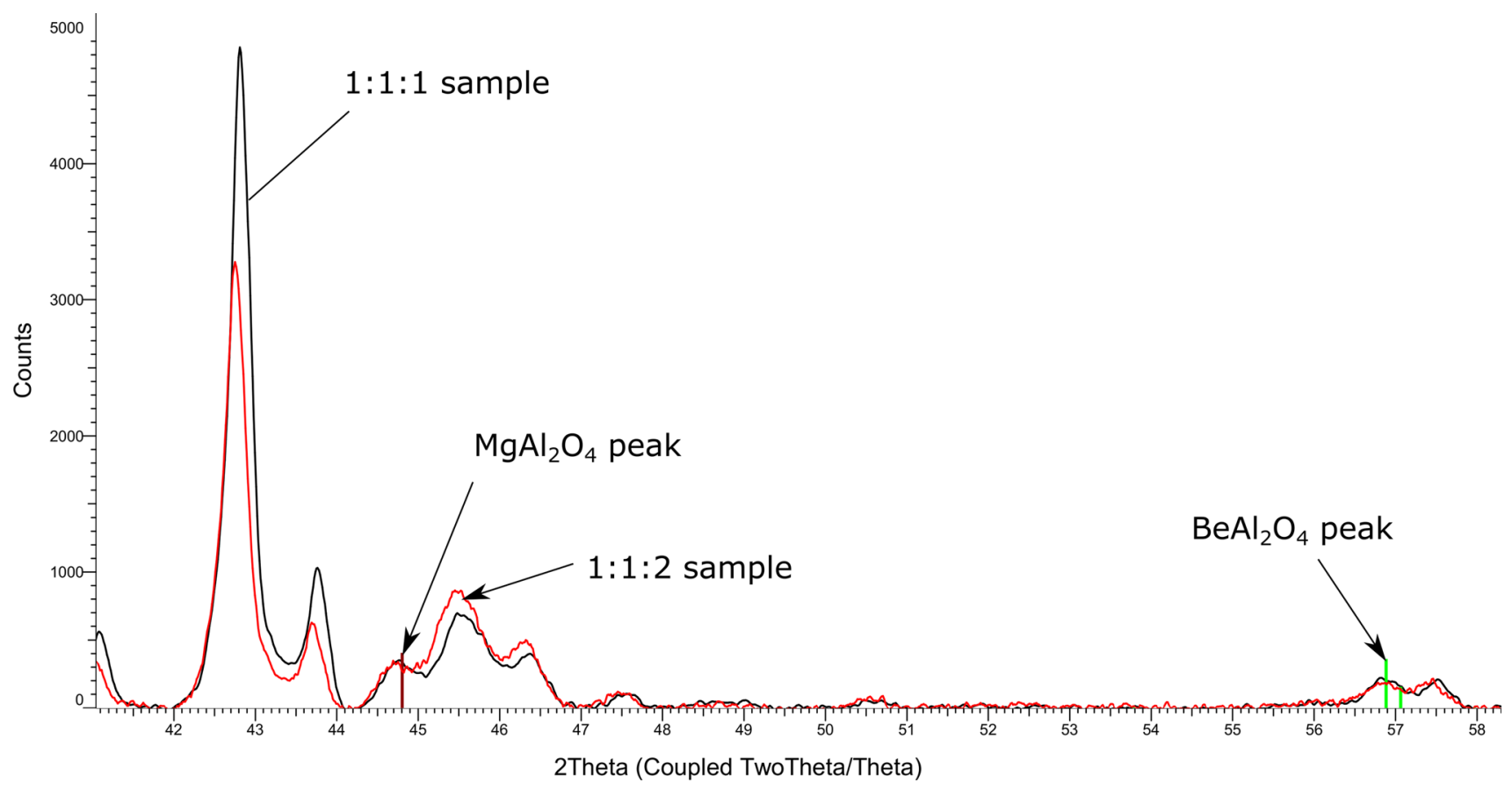

Fig. 15-A portion of the XRD patterns from oxide mixing experiments showing both the $1: 1: 1$ and $1: 1: 2$ mixing ratios. $\mathrm{Both}^{\mathrm{BeAl}} \mathrm{O}_{4}$ and $\mathrm{MgAl}_{2} \mathrm{O}_{4}$ are seen to form in similar amounts (same peak intensity) where the binary oxides show different amounts. Unlabeled peaks correspond to the binary $\mathrm{MgO}, \mathrm{BeO}$, or $\mathrm{Al}_{2} \mathrm{O}_{3}$ oxides phases.

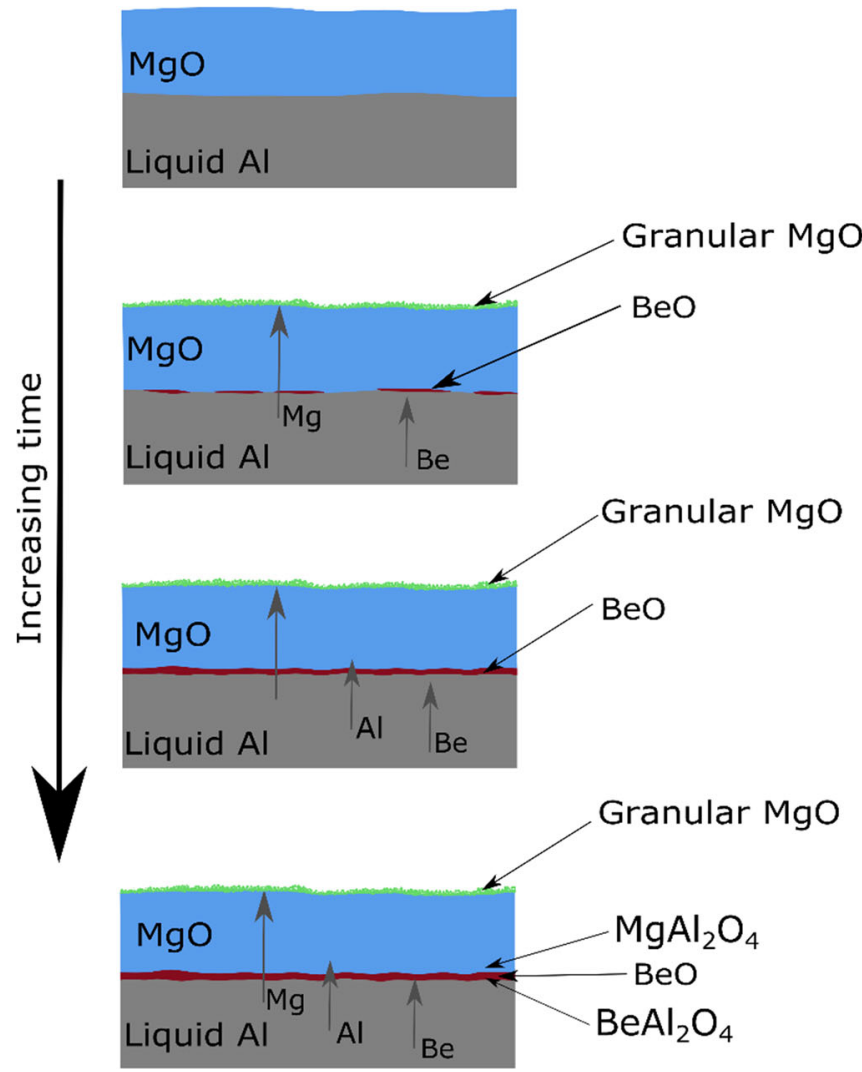

1. Native MgO oxide layer due to oxidation at room temperature and heating up to molten state. $\mathrm{Be}$ is homogeneously distributed throughout the melt

2. Mg is transported from the bulk through the native oxide layer and forms a new granular oxide layer. $\mathrm{Be}$ is transported to the oxide-metal interface and reacts with the native oxide layer to form $\mathrm{BeO}$.

3. BeO layer creates a barrier between the melt and native oxide layer. $\mathrm{Mg}$ and $\mathrm{Al}$ will diffuse across the $\mathrm{BeO}$ layer.

4. Due to the low free $\mathrm{Mg}$ content in the native oxide layer the $\mathrm{MgAl}_{2} \mathrm{O}_{4}$ phase becomes stable and forms. Additionally the $\mathrm{BeAl}_{2} \mathrm{O}_{4}$ phase is stable due to the low amount of free Be and forms. Breakaway oxidation is delayed as the formation of the $\mathrm{MgAl}_{2} \mathrm{O}_{4}$ spinel phase, which is key to breakaway oxidation, is controlled by $\mathrm{Al}$ diffusion through $\mathrm{BeO}$.

Fig. 16-Proposed mechanism behind the protective effect of $\mathrm{Be}$ on $\mathrm{Mg}$-containing $\mathrm{Al}$ melts. 
For the oxide stability tests, the similar heights of the $\mathrm{BeAl}_{2} \mathrm{O}_{4}$ and $\mathrm{MgAl}_{2} \mathrm{O}_{4}$ peaks for both oxide mixing ratios indicates a similar amount of the phases in both samples regardless of the initial mixing ratio. This means that both the $\mathrm{BeAl}_{2} \mathrm{O}_{4}$ and $\mathrm{MgAl}_{2} \mathrm{O}_{4}$ spinel phases exist and can form simultaneously in a system containing $\mathrm{Mg}$, $\mathrm{Be}, \mathrm{Al}$, and $\mathrm{O}$.

Based on the results and discussion above the proposed reaction and protection mechanism of an $\mathrm{Al}-\mathrm{Mg}$ alloy containing $\mathrm{Be}$ is given in Figure 16. The proposed steps in the oxidation are:

1. The starting point of this model is taken as a liquid Al-Mg alloy with a layer of $\mathrm{MgO}$. The $\mathrm{MgO}$ layer will form as a result of oxidation at room temperature, heating, and melting. While $\mathrm{BeO}$ is a more stable oxide than $\mathrm{MgO}$, the initial oxide layer is found to be $\mathrm{MgO}$ as the activity of $\mathrm{Mg}$ is significantly higher than the Be at ppm levels. Any Be present on the surface will have reacted to form $\mathrm{BeO}$; however, given the small amounts of Be that would be present at the surface, any $\mathrm{BeO}$ formed is neglected at this stage.

2. As metallic Be interacts with the $\mathrm{MgO}$ layer, it will react to form $\mathrm{BeO}$ and $\mathrm{Mg}$ per Eq. [2] rather than the direct oxidation with oxygen through Eq. [3]. Due to the rapid diffusion of $\mathrm{Be}$ in the liquid alloy, an elevated concentration of Be compared with the bulk alloy will form resulting in a higher Be activity at the oxide-metal interface. This higher Be activity will help to drive the oxidation of $\mathrm{Be}$ to $\mathrm{BeO}$. The diffusion of $\mathrm{Be}$ to the oxide-metal interface will happen rapidly given the small atomic radius of the $\mathrm{Be}$ atom as the diffusion coefficient is inversely proportional to the atomic radius. With the atomic radius of $\mathrm{Be}$ at $1.12 \AA$ compared to $1.60 \AA$ for $\mathrm{Mg}$ and $1.43 \AA$ for $\mathrm{Al}$, the Be should diffuse rapidly through the liquid $\mathrm{Al}$ allowing for significant and rapid Be concentration at the oxide-metal interface. ${ }^{[12]}$

$$
\begin{gathered}
\mathrm{MgO}+\mathrm{Be}=\mathrm{BeO}+\mathrm{Mg} \\
\mathrm{Be}+\mathrm{O}=\mathrm{BeO}
\end{gathered}
$$

3. As holding time in the liquid state increases, a continuous BeO layer will begin to form at the oxide-metal interface since the primary source of oxygen for the oxidation of $\mathrm{Be}$ is the $\mathrm{MgO}$ layer. The areas on the $\mathrm{BeO}$ layers that are the thinnest will have the highest access to oxygen and see the most growth. This results in a relatively uniform layer of $\mathrm{BeO}$ covering the entire oxide-metal interface. While this BeO layer is forming, $\mathrm{Mg}$ from the metal and as a byproduct from Be oxidation, will continue to diffuse outward and cause the granular oxidation on the surface of the oxide.

Once the $\mathrm{BeO}$ layer has formed and covered the entire oxide-metal interface, a barrier between the metal and oxide has been established, and diffusion across this $\mathrm{BeO}$ layer is required for any further oxidation of $\mathrm{Be}, \mathrm{Mg}$, or $\mathrm{Al}$ to occur.
For the 100 ppm Be samples, the $\mathrm{BeO}$ layer ranges from 15 to $50 \mathrm{~nm}$ thick and an average of around $40 \mathrm{~nm}$ after 6 hours at $700^{\circ} \mathrm{C}$. The layer for the $2 \mathrm{ppm}$ samples could not be observed on the FIB, and therefore must be at least one order of magnitude thinner. If the entire Be content in the sample was oxidized to $\mathrm{BeO}$, the thickness of the layer would be approximately $250 \mathrm{~nm}$ for the $100 \mathrm{ppm}$ sample and $5 \mathrm{~nm}$ for the $2 \mathrm{ppm}$ sample based on the sample size used. Based on the average $\mathrm{BeO}$ layer thickness, 16 pct of the Be in the $100 \mathrm{ppm}$ sample was oxidized at $700{ }^{\circ} \mathrm{C}$ indicating a strong tendency to segregate to the oxide layer. Regardless of the thickness of this layer, it must act as an effective barrier to the diffusion.

4. The MgO layer will be nearly free of metallic $\mathrm{Mg}$ and $\mathrm{Al}$, and thus, a diffusion gradient will be established and flux of these elements across the $\mathrm{BeO}$ layer will develop. The diffusion coefficients of $\mathrm{Mg}$ and $\mathrm{Al}$ through the hexagonal $\mathrm{BeO}$ layer are not available at this momemt, rendering the calculations of the actual rates of $\mathrm{Mg}$ and $\mathrm{Al}$ diffusion across this layer as not possible. The smaller atomic size of Be compared with $\mathrm{Mg}$ should significantly reduce the ability of $\mathrm{Mg}$ to diffuse outward through the $\mathrm{BeO}$ layer compared with the initial $\mathrm{MgO}$ layer. In addition, the $\mathrm{MgO}$ layer is generally considered to be a noncontinuous layer and acts as a poor transport barrier. The smaller diameter and higher concentration of $\mathrm{Al}$ compared with $\mathrm{Mg}$ means Al will have a higher flux across the $\mathrm{BeO}$ layer than $\mathrm{Mg}$. Given the limited supply of both $\mathrm{Mg}$ and $\mathrm{Be}$ to the system, it is assumed that the $\mathrm{MgAl}_{2} \mathrm{O}_{4}$ and $\mathrm{BeAl}_{2} \mathrm{O}_{4}$ phases will be the most stable and form via Eqs. [1] and [4]. The oxide-stability experiments show that both these phases can exist under nonequilibrium conditions. It is well established that the $\mathrm{MgAl}_{2} \mathrm{O}_{4}$ phase only becomes stable after the metallic $\mathrm{Mg}$ activity has dropped below 0.023 . This has not been shown for the $\mathrm{BeAl}_{2} \mathrm{O}_{4}$ spinel, but given the similar oxidation characteristics, it is assumed the same is also true for the $\mathrm{BeAl}_{2} \mathrm{O}_{4}$ phase.

$$
4 \mathrm{BeO}+2 \mathrm{Al}=\mathrm{BeAl}_{2} \mathrm{O}_{4}+3 \mathrm{Be}
$$

Breakaway oxidation is delayed as the formation of the $\mathrm{MgAl}_{2} \mathrm{O}_{4}$ phase is now diffusion controlled. Before the $\mathrm{BeO}$ layer formed, the $\mathrm{MgO}$ was in direct contact with Al. This allowed rapid transformation of $\mathrm{MgO}$ to $\mathrm{MgAl}_{2} \mathrm{O}_{4}$. The $\mathrm{BeO}$ layer now acts as a barrier separating the $\mathrm{Al}$ from the $\mathrm{MgO}$ causing the $\mathrm{MgAl}_{2} \mathrm{O}_{4}$ reaction rate to become tied to the diffusion of $\mathrm{Al}$ across $\mathrm{BeO}$.

Based on the proposed mechanism above suggestions for alternative alloying additions can be made. An alternate element should react to form a diffusion barrier at the oxide metal interface. To encourage the formation of this layer an alternative element would need to have a strong tendency to segregate to the oxide-metal interface and readily react to from a protective layer. From this several candidates can be proposed, such as other group 2 elements or rare earth elements. In regards to the group 2 elements, $\mathrm{Sr}$ seems to 
be the obvious candidate as it oxidizes preferentially to magnesium. Previous studies on the effects of $\mathrm{Sr}$ on the oxidation have shown mixed results with its effectiveness for inhibiting oxidation. ${ }^{[13,14]}$ Rare earth elements stand out as a potential alternative as they are surface active and will readily react. Yttrium has seen usage as an alloying element to reduce the oxidation of solid $\mathrm{Mg}$ alloys at $500{ }^{\circ} \mathrm{C}$ and may prove effective in controlling the oxidation of liquid AlMg alloys. ${ }^{[15-17]}$ The effect of both $\mathrm{Sr}$ and rare earth elements on the oxidation will be the subject of further research.

\section{CONCLUSION}

Industrial (2 ppm Be) and model (100 ppm Be) $\mathrm{Al}-\mathrm{Mg}$ alloys have been oxidized in air at temperatures between $550{ }^{\circ} \mathrm{C}$ and $750{ }^{\circ} \mathrm{C}$ in order to establish the mechanism by which Be provides oxidation protection to Al-Mg alloys. Based on the results from FIB and XPS studies of the oxidized surface, a protection mechanism has been proposed, and the following conclusions have been made:

- On samples below the melting point, Be forms as $\mathrm{BeO}-\mathrm{Al}_{2} \mathrm{O}_{3}$ growths on the surface in combination with $\mathrm{MgO}$.

- The composition of these growths does not correspond to a $\mathrm{BeAl}_{2} \mathrm{O}_{4}$ phase, but rather a $\mathrm{BeO}-\mathrm{BeAl}_{2} \mathrm{O}_{4}$ phase. The ratio of $\mathrm{Al}$ oxide: $\mathrm{Be}$ oxide increases with depth in the growth.

- On samples below the melting point, the surface growths form predominantly in areas most prone to oxidation such as grain boundaries, and thus act to slow the oxidation as a network of $\mathrm{MgO}$ continues to form and grow around the $\mathrm{BeO}-\mathrm{BeAl}_{2} \mathrm{O}_{4}$ growths.

- On molten samples, the $\mathrm{BeO}$ forms a uniform layer of 15 to $50 \mathrm{~nm}$ thickness under an initial $\mathrm{MgO}$ surface layer for a sample with $100 \mathrm{ppm}$ Be and $4.5 \mathrm{pct} \mathrm{Mg}$.

- This $\mathrm{BeO}$ layer acts as a barrier to $\mathrm{Mg}$ and $\mathrm{Al}$ diffusion into the oxide thus slowing $\mathrm{MgO}$ and $\mathrm{MgAl}_{2} \mathrm{O}_{4}$ formation.

In addition, the stability of the $\mathrm{MgO}-\mathrm{BeO}-\mathrm{Al}_{2} \mathrm{O}_{3}$ ternary oxide system and the formation of $\mathrm{MgAl}_{2} \mathrm{O}_{4}$ or $\mathrm{BeAl}_{2} \mathrm{O}_{4}$ were studied along with the metal-oxide reaction of an $\mathrm{Al}$ drop with trace $\mathrm{Be}$ amounts on $\mathrm{Al}_{2} \mathrm{O}_{3}$ and $\mathrm{MgO}$, and experiments have been carried out where the following were found:

- Both $\mathrm{MgAl}_{2} \mathrm{O}_{4}$ and $\mathrm{BeAl}_{2} \mathrm{O}_{4}$ will form in the ternary $\mathrm{MgO}-\mathrm{BeO}-\mathrm{Al}_{2} \mathrm{O}_{3}$ oxide system after a holding time of 7 hours at $1100{ }^{\circ} \mathrm{C}$.

- Addition, of 30 and $60 \mathrm{ppm}$ of $\mathrm{Be}$ to $\mathrm{Al}$ will have negligible impact on the wetting angle on a $\mathrm{Al}_{2} \mathrm{O}_{3}$ substrate. The same alloys on an $\mathrm{MgO}$ substrate will rapidly react to form an $\mathrm{MgAl}_{2} \mathrm{O}_{4}$ reaction layer.

\section{ACKNOWLEDGMENTS}

This paper has been funded by the SFI Metal Production (Centre for Research-based Innovation, 237738). The authors gratefully acknowledge the financial support from the Research Council of Norway and the partners of the SFI Metal Production. Further, the authors would like to thank Ingeborg-Helene Svenum, Martin Fleissner, Per Erik Vullum, and Christian Simensen of SINTEF for their help in the analysis of the samples, and the University of Pittsburg especially Prof. Brian Gleeson for the kind permission to use the laboratory space and fruitful discussions.

\section{OPEN ACCESS}

This article is distributed under the terms of the Creative Commons Attribution 4.0 International License (http://creativecommons.org/licenses/by/4.0/), which permits unrestricted use, distribution, and reproduction in any medium, provided you give appropriate credit to the original author(s) and the source, provide a link to the Creative Commons license, and indicate if changes were made.

\section{REFERENCES}

1. S. Balicki: Prace Inst., 1958, vol. 10, pp. 208-13.

2. W. Thiele: Aluminium, 1962, vol. 38, pp. 780-86.

3. C. Cochran, D. Belitskus, and D. Kinosz: Metall. Mater. Trans. B, 1977, vol. 8B, pp. 323-32.

4. G. Sigworth: Best Practices in Aluminum Metalcasting, American Foundry Society, Schaumburg, IL, 2014.

5. K. Surla, F. Valdiveso, M. Pijolat, M. Soustelle, and M. Prin: Solid State Ionics, 2001, vol. 143, pp. 355-65.

6. S. Bao: Ph.D. Thesis, NTNU, Trondheim, Norway, 2011, pp. 4-80.

7. N. Smith: Light Metals 2017, TMS2017, San Deigo, pp. 146574.

8. I. Haginoya and T. Fukusako: Trans. JIM, 1983, vol. 24 (9), pp. 613-19.

9. K. Wefers: Aluminum, 1981, vol. 57, pp. 722-26.

10. N. Smith: Light Metals, TMS2018, Phoenix, 2018, pp. $913-$ 19.

11. M. Syvertsen: Light Metals, TMS2017, San Diego, 2015, pp. 1451-55.

12. T. Engh: Principles of Metal Refining, 1st ed., Oxford University Press, New York, NY, 1992, pp. 114-17.

13. O. Ozdemir, E. Gruzleski, and A. Drew: Oxid. Metals, 2009, vol. 72 , pp. 241-57.

14. S. Miresmaeili: Metal, 2005, vol. 2005, pp. 223-31.

15. X. Wang, X. Zeng, G. Wu, and S. Yao: Appl. Surf. Sci., 2006, vol. 253 , pp. $2437-42$.

16. X. Wang, X. Zeng, G. Wu, S. Yao, and Y. Lai: Appl. Surf. Sci., 2007, vol. 253, pp. 3574-80.

17. X. Wang, X. Zeng, G. Wu, and S. Yao: Mater. Lett., 2007, vol. 61, pp. $968-70$. 